\title{
THE DIFFUSION OF ENERGY EFFICIENCY IN BUILDING
}

\author{
By NILS KOK, MARQUISE MCGRAW, AND JOHN M. QUIGLEY*
}

There exists an apparently intractable contradiction between the slow diffusion of energy efficient technologies and the profitability of these measures. Early research on consumer choice suggested that the discount rate applied to more energy efficient appliances and durable goods was unreasonably high, approaching twenty percent. (See Jerry A. Hausman, 1979.) This “energy paradox" has regained currency in the recent debate on carbon reduction and climate change -- the durability of real capital implies that the building sector has large effects upon greenhouse gas emissions and upon energy use.

Although the slow diffusion of more energyefficient technologies in buildings is a widelydiscussed challenge to the neoclassical theory of investment -- at least among engineers (Hunt Alcott and Sendhil Mullainathan, 2010) -recent trends suggest that the number of buildings that are labeled as "energy efficient," "sustainable," or "green," has surged over the past decade. Energy certificates for buildings are a testimony to improved building technologies, which are difficult to observe.

Existing commercial buildings can receive an Energy Star certification from the US Environmental Protection Agency (EPA) if the source energy use of the building is in the top

\footnotetext{
* Kok: Department of Finance, School of Business and Economics, Maastricht University, 6200MD, Maastricht, Netherlands (e-mail: n.kok@maastrichtuniversity.nl); McGraw: Department of Economics, 549 Evans Hall, University of California, Berkeley, CA 94720-3880, (e-mail: mmcgraw@econ.berkeley.edu); Quigley: Department of Economics, 549 Evans Hall, University of California, Berkeley, CA 94720-3880, (e-mail: quigley@econ.berkeley.edu). Financial support was provided by the Mistra Foundation, by the Royal Institution of Chartered Surveyors, and by the University of California Center for Energy and Environmental Economics. Kok is supported by a VENI grant from the Dutch Science Foundation (NWO). We are grateful to William Wheaton and Jon Southard of CBRE Econometric Advisors for facilitating access to some of the data used in this analysis. A more complete version of this paper appears at http://urbanpolicy.berkeley.edu.
}

quarter of all comparable buildings. As of November 2010, some 12,000 commercial buildings had received the label.

In a parallel effort, the US Green Building Council (USGBC), a private nonprofit organization, has developed the Leadership in Environmental and Energy Design (LEED) green building rating system to encourage the "adoption of sustainable green building and development practices." The requirements for the certification of LEED buildings are substantially more complex than those for the award of an Energy Star rating. The LEED certification process measures six distinct components of sustainability (one of which is energy performance). The LEED system of multiple ratings has become a dominant force in the commercial and institutional building market in the US. Many states and cities require a minimum LEED certification for new commercial construction and for renovations. More than 6,500 commercial buildings (about a billion square feet) had been LEED-certified as of November 2010.

Presumably, buildings certified for energy efficiency or sustainability incorporate technologies that systematically reduce resource usage and operating costs. Increased energy efficiency and other elements related to "sustainability" both contribute to increases in rents, occupancy rates and asset values in commercial offices. Moreover, among rated buildings, incremental energy savings are roughly capitalized into asset values (Piet M.A. Eichholtz, Nils Kok and John M. Quigley, 2010).

In this paper, we analyze the spread of energy efficient technology in the built environment. "Technology" is itself difficult to measure, but labels, like patents, offer an indirect approach to assessing the diffusion of improved technology. (See Wolfgang Keller, 2004.) Using a detailed panel of 48 MSAs observed annually during a fifteen-year period, we trace the diffusion of buildings certified for 
energy efficiency and sustainability across US metropolitan areas. We analyze the geographic patterns and dynamics, relating industry composition, input prices, local climate, economic conditions, and characteristics of the local commercial property market to variations in energy-efficient office space.

\section{Dynamics of Energy Efficiency in Buildings}

We use the Energy Star and LEED certification to measure the diffusion of energy efficiency in building. ${ }^{1}$ We record the number of buildings and the volume of Energy Star and LEED-certified office space reported annually by the EPA and the USGBC for the period January 1995-August 2010. We estimate the importance of energy-efficient office space in the private market using information on the size of commercial property markets across MSAs. ${ }^{2}$ Figure 1 presents the aggregate diffusion curves of Energy Star and LEED certification for 48 US metropolitan areas. $^{3}$ Energy-Starcertified buildings are currently about ten percent of the total office market, but measured by the volume of space, the fraction is three times as high -- some thirty percent.

The apparent relation between the adoption of energy-efficient technology and building size corroborates more general evidence on technology diffusion; larger companies and production facilities are more likely to adopt new technologies and to adapt more quickly to

\footnotetext{
${ }^{1}$ The criteria for certification under these two programs are hardly mutually exclusive; the owners of a number of buildings certified by one program apply for and receive certification by the other.

2 These data were provided by CBRE Econometric Advisors (CBRE-EA), a major provider of research services to owners and investors in the U.S. and Canadian commercial real estate markets. We utilize information from their "Building Stock Database": https://www.cbreea.com.

${ }^{3}$ Note that the CBRE Building Stock Database is confined to buildings that are considered "competitive" -- this criterion is related to building size and differs by market. For example, most markets have a building size of 10,000 sq. ft. as one of the criteria for "competitive." As a result, the estimated fractions of energy efficient space presented in this paper are biased upwards, by at least by some small amount. To our knowledge, the CBRE database is the only consistent source of reliable and consistent time-series information on the stock of commercial buildings.
}

changed circumstances (Nancy L. Rose and Paul L. Joskow, 1990). The diffusion curve for Energy-Star-labeled space follows the welldocumented S-shaped pattern of innovation diffusion (Zvi Griliches, 1957). The figure shows that the diffusion of LEED-certified space is still in early stages. The later start of the LEED system and its initial focus on new construction help explain the slower diffusion rate.

In the longer version of this paper, we report the diffusion curves for a selection of US metropolitan areas. The timing of adoption and growth in energy-efficient office space differs quite markedly across metropolitan areas. There is also substantial variation between the initial start and the subsequent growth in the diffusion of LEED labels across markets.
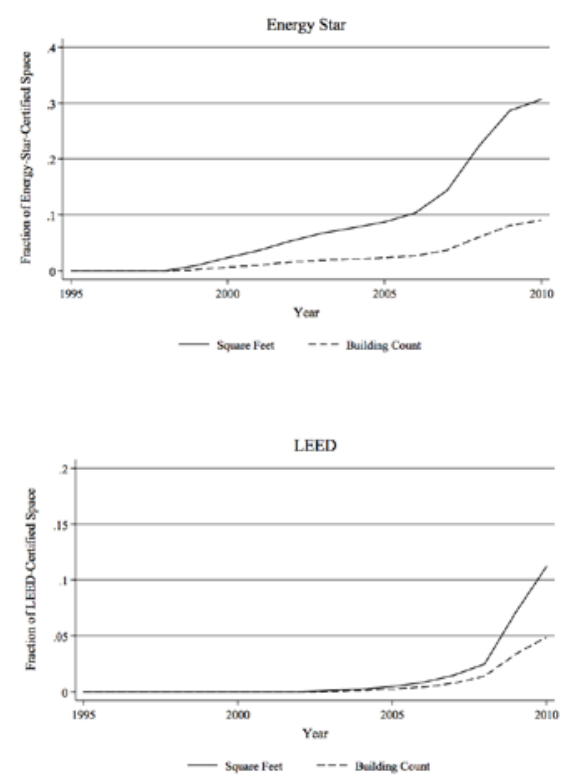

FIGURE 1. LEED AND ENERGY STAR DYNAMICS EXTENT OF CERTIFIED OFFICE SPACE

\section{Explaining the Diffusion of Energy Efficiency}

We hypothesize that the variation in diffusion is related to variations across buildings and property markets in the expected cost savings from adopting energy-efficient technology; variations in local economic conditions that affect the appropriability of gains; and other characteristics that influence 
the expected profitability of the adoption of the energy-efficient innovations. Of course, political and institutional characteristics, such as regulation and ideology, may also play an important role in explaining the adoption of energy-efficient technology.

Specifically, we measure Climatic Conditions (cooling and heating degree-days) ${ }^{4}$ and Energy Prices (electricity) for each MSA and year. ${ }^{5}$

We also include General Economic Conditions and Industry Composition by MSA and year. By including these measures, we are able to examine the relationship between energy-efficient building technologies and local economic prosperity. For example, we can measure the extent to which "green" is viewed as a luxury good that provides a "warm glow," (Brian Roe et al., 2001). ${ }^{6}$

Many local jurisdictions have adopted "green" procurement policies that include the commercial space rented by the public sector; thus we hypothesize a positive relation between the demand for more energy-efficient space and the relative size of the government, measured by the number of people employed by government, as a fraction of total employment in the MSA.

It is also argued that some ancillary benefits of "green" building, such as improved employee productivity and morale, may particularly benefit the space-intensive service sector (Piet M.A. Eichholtz et al., 2010). We measure the importance of the service sector relative to total MSA employment. ${ }^{7}$

We also measure Property Market Conditions and the availability of Building Professionals. We expect that the adoption of Energy Star and LEED certificates is positively

\footnotetext{
${ }^{4}$ National Weather Service, http://www.cpc.ncep.noaa.gov.

${ }^{5}$ Energy prices were constructed using revenue and sales data reported for each utility by the U.S. Energy Information Administration, mapped to counties and ultimately averaged by MSA (weighted by sales). http://www.eia.doe.gov/cneaf/electricity/page/eia861.html. ${ }^{6}$ Income is measured by average wages and salaries. BEA, http://www.bea.gov/regional/docs/reis2008dvd.cfm.

${ }^{7}$ We aggregate the number of jobs in "financial activities," "professional and business services," "information," and "other services," as a fraction of total employment in the MSA. BLS, ftp://ftp.bls.gov/pub/special.requests/cew.
}

related to new construction in a metropolitan area, which in turn depends on market fundamentals such as the vacancy rate and rental levels. We measure the characteristics of the local property market by: the total office stock, the average vacancy rate, and the average property price. ${ }^{8}$

The design and construction of energy efficient commercial space requires specific technical knowledge, supplied by architects and engineers, among others. Currently, more than 150,000 designers, contractors, and consultants have earned the designation "LEED Accredited Professional" (LEED AP). We measure the availability of "human capital" by the number of LEED APs registered by MSA and year. ${ }^{9}$

We also measure Political Ideology and Local Regulation; both may influence the adoption of energy efficiency and "green" technologies in commercial building. We measure political preferences in each MSA by the percentage vote for Ronald Reagan in 1984 and the percentage vote for George H.W. Bush in $1988 .{ }^{10}$

Government policies, such as regulation and incentives, may also play an important role in explaining the growth in adoption of energy efficient innovations (Adam B. Jaffe and Karen Palmer, 1997). The US Green Building Council registers policies related to "green" building by civil division. We construct a simple measure of the "intensity" of green-building-related policies by aggregating LEED-related policies by MSA by year. ${ }^{11}$

\section{A. Model and Results}

We exploit the dynamics in the dispersion of energy-efficient office space across metropolitan areas by modeling the diffusion of labeled office space over time and geographical markets in a straightforward manner:

\footnotetext{
${ }^{8}$ The average rental price is the lease quoted for space in the average building, corrected for hedonic characteristics. The average property price is estimated for a 100,000 square foot building and is derived from the average rent, the vacancy rate and the prevailing capitalization rate in the MSA.

${ }^{9}$ GBCI, http://www.gbci.org.

${ }^{10}$ CQ Press, http://library.cqpress.com/elections/export.php

${ }^{11}$ USGBC, http://www.usgbc.org/government.
} 
(1) $\Delta$ Fraction $_{i t}=\alpha+\beta \Delta \mathbf{X}_{i t-2}+\varepsilon_{i t}$

where $\Delta$ Fraction $_{i t}$ is the annual change in the fraction of certified office space, $\Delta \mathbf{X}_{i t-2}$ is a vector of local economic conditions, energy prices, and property market characteristics. ${ }^{12}$ We express the dispersion of energy-efficiency labels across time and space in first differences, to control for time-invariant unobserved effects specific to MSAs. The pattern of diffusion of energy efficiency and "sustainability" in buildings is highly autocorrelated, so we estimate equation (1) using a simple model of first order serial correlation; to account for possible endogeneity, we estimate results following the Arellano-Bond procedure, where all covariates are instrumented by their own lagged values in a GMM estimation.

Table 1 summarizes the relationship between the diffusion of energy-efficient office space and the presumed key determinants of the adoption of energy-efficient technology in buildings. ${ }^{13}$ Columns (1) through (5) present predictions about the diffusion of Energy Star certification across the 48 MSAs; Columns (6) through (10) present predictions about the diffusion of LEED certification.

Income is clearly important in explaining the diffusion of Energy-Star-certified buildings over space and time. In areas with higher income and stronger income growth, the adoption of energy-efficient building practices is more rapid. In all five regressions explaining the diffusion of Energy Star certification, the price of commercial electricity is highly significant. The measure of the relative size of the property market is significant in all models as well -- in markets with a larger supply of office space per employee, the adoption of energy-efficient technologies is faster.

The results documented in Column (6) suggest that the price of energy is less relevant to the geographical and temporal variation in the diffusion of LEED-certified office space.

\footnotetext{
${ }^{12}$ We use a two-year lag of the explanatory variables to account for the time necessary to complete property renovations and new property development.

${ }^{13}$ Results are reported for linear GMM models only. Results from other specifications are reported in the longer version of this paper.
}

However, the diffusion of LEED certification appears to be influenced by income. The measure of property market conditions is not significant in the models.

These differences in the regression results may arise from the criteria employed for the award of Energy Star and LEED certification. Energy Star certification is based only upon energy efficiency in building operations: this is clearly more important in property markets in which the price of energy is higher. LEED certification is based on a variety of aesthetic features of building, and energy efficiency is one component. These features are apparently more important in metropolitan areas where incomes are higher, which may be related to the positive association between income and the willingness to pay for environmental goods (Brian Roe, et al., 2001). Also, the ancillary benefits of LEED-certification may be more valuable in areas where incomes, and thus the average value-added per employee, are higher.

Columns (2) through (5) summarize models in which several additional variables are included as regressors. ${ }^{14}$ Column (2) provides evidence that Energy Star certification has increased in markets with lower unemployment rates. Higher demand for office space, leading to more favorable conditions in the property market (and more new construction), clearly affects the diffusion of energy-efficient technologies in building. This is also reflected in the importance of service sector jobs in the local economy -- more white-collar jobs translate into higher demand for office space.

Of course, we can also measure the conditions in the commercial property market directly. Column (3) includes the (lagged) vacancy rate and average property values across MSAs and over time. The adoption of energy-efficient and "green" building practices is more rapid in healthier property markets. The expected payoff from investments in energy efficiency increases with lower volatility in occupancy rates, and the value increment that "green" buildings may command in the marketplace is more significant if property

\footnotetext{
${ }^{14}$ The variable measuring personal income is excluded from these models, because it is strongly related to some of the other variables.
} 
prices are higher. Naturally, lower vacancy rates will also trigger new construction, which may also increase the fraction of rated space.

In column (4), we evaluate the impact of climatic conditions and building professionals on the diffusion of Energy Star certification. The energy efficiency of building technology is unrelated to more extreme climatic circumstances. The presence and growth of "human capital" is negatively related to the diffusion of energy efficient space. LEED Accredited Professional accreditation is apparently unrelated to engineering knowledge on energy efficiency in commercial buildings.

Column (5) relates the presence of LEEDrelated policies to the adoption of energy efficiency innovations, but there is no evidence of spillover effects of these specific regulations and incentives.

Columns (6) through (10) present similar models to explain the diffusion of LEEDcertified buildings. In common with the analysis for Energy Star, the adoption of LEED certification seems to be a consequence of employment and property market fundamentals. Areas with lower unemployment have stronger growth in "green" construction or retrofits. Higher vacancy rates and lower property values hamper the diffusion of "green" building innovations.

Importantly, the number of building professionals trained to perform LEED audits has a positive effect on the growth of "green" space, as reported in Column (4). This finding supports the notion that the presence of professional or business channels to acquire specific information about an innovation and its technical properties is an important determinant of technology diffusion (Bronwyn Hall, 2003). Also, local policies designed to stimulate more "sustainable" building practices have a significantly positive effect on the diffusion of LEED-certified space, although we cannot distinguish between the effects of regulations or other incentives.

\section{Conclusions}

Despite much discussion about the "energy paradox" in the built environment, the diffusion of energy efficiency and "sustainability" technology in building has been widespread and rapid. This paper documents this diffusion over time and across U.S. property markets. By 2010, about thirty percent of all commercial office space in the 48 largest metropolitan areas was certified for energy efficiency by Energy Star. About eleven percent of office space was certified as "sustainable" by LEED. But there is considerable variation across metropolitan areas. In Los Angeles, for example, more than half of all commercial office space has been certified for energy efficiency.

The diffusion has been more rapid in metropolitan areas with higher incomes, and in those with sound property market fundamentals. These findings suggest that the property markets that face more dire economic conditions (such as Dallas, Detroit and Tampa) will lag behind in the energy efficiency of their commercial office stock.

Importantly, the diffusion of energy efficient technology in buildings is more responsive to energy prices than is the diffusion of buildings certified for "sustainability." Commercial property markets -- and, more specifically, building owners -- seem to evaluate the impact of resource consumption upon the profitability of investment in real capital. This lends considerable support to the efficiency of energy investment decisions in the business sector, certainly compared to the "energy paradox" decried in the residential sector.

Finally, the diffusion of "green" space is facilitated by factors such as trained building professionals and governmental policies. LEED policies and the LEED professional education program seem to be effective in stimulating the growth of "green" space, but the consequences of this growth on energy demand remain unclear.

\section{REFERENCES}

Alcott, Hunt, and Sendhil Mullainathan. 2010. "Behavior and Energy Policy." Science, 327: 1204-05.

Eichholtz, Piet M.A., Nils Kok, and John M. Quigley. 2010. "Doing Well by Doing Good: Green Office Buildings." American Economic 
Review, 100(5): 2494-511.

Griliches, Zvi. 1957. "Hybrid Corn: An Exploration in the Economics of Technical Change." Econometrica, 25(4): 501-22.

Hall, Bronwyn. 2004. "Innovation and Diffusion." In Handbook of Innovation, ed. Jan Fagenberg, David Mowery and Richard R. Nelson, Oxford: Oxford University Press.

Hausman, Jerry A. 1979. "Individual Discount Rates and the Purchase and Utilization of Energy-Using Durables." Bell Journal of Economics, 10: 33-54.

Jaffe, Adam B., and Karen Palmer. 1997. "Environmental Regulation and Innovation: A Panel Data Study." Review of Economics and
Statistics, 16: 610-19.

Keller, Wolfgang. 2004. "International Technology Diffusion." Journal of Economic Literature, 42(3): 752-82.

Roe, Brian, Mario F. Teisl, Alan Levy, and Matthew Russell. 2001. "US Consumers' Willingness to Pay for Green Electricity." Energy Policy, 29(11): 917-25.

Rose, Nancy L., and Paul L. Joskow. 1990. "The Diffusion of New Technologies: Evidence from the Electric Utility Industry." RAND Journal of Economics, 21(3): 354-73.

TABLE 1-ARELLANO-BOND GMM REGRESSION RESULTS

\begin{tabular}{|c|c|c|c|c|c|c|c|c|c|c|}
\hline & \multicolumn{5}{|c|}{ Energy Star } & \multicolumn{5}{|c|}{ LEED } \\
\hline & (1) & (2) & (3) & (4) & (5) & (6) & (7) & (8) & (9) & (10) \\
\hline $\begin{array}{l}\text { Income } \\
\text { (\$ thousands) }\end{array}$ & $\begin{array}{c}\mathbf{0 . 0 0 3} \\
{[0.000]}\end{array}$ & & & & & $\begin{array}{c}\mathbf{0 . 0 0 1} \\
{[0.000]}\end{array}$ & & & & \\
\hline $\begin{array}{l}\text { Unemployment Rate } \\
\text { (percent) }\end{array}$ & & $\begin{array}{l}-\mathbf{0 . 6 3 1} \\
{[0.113]}\end{array}$ & & & & & $\begin{array}{l}-\mathbf{0 . 2 6 9} \\
{[0.074]}\end{array}$ & & & \\
\hline $\begin{array}{l}\text { Share of Government Jobs } \\
\text { (percent) }\end{array}$ & & $\begin{array}{l}-0.070 \\
{[0.049]}\end{array}$ & & & & & $\begin{array}{l}-0.016 \\
{[0.031]}\end{array}$ & & & \\
\hline $\begin{array}{l}\text { Share of Service Sector Jobs } \\
\text { (percent) }\end{array}$ & & $\begin{array}{c}\mathbf{0 . 0 9 7} \\
{[0.057]}\end{array}$ & & & & & $\begin{array}{c}0.022 \\
{[0.036]}\end{array}$ & & & \\
\hline $\begin{array}{l}\text { Commercial Vacancy Rate } \\
\text { (percent) }\end{array}$ & & & $\begin{array}{l}-\mathbf{- 0 . 0 0 1} \\
{[0.000]}\end{array}$ & & & & & $\begin{array}{l}-\mathbf{0 . 0 0 0} \\
{[0.000]}\end{array}$ & & \\
\hline $\begin{array}{l}\text { Average Commercial Property } \\
\text { (\$ million) }\end{array}$ & & & $\begin{array}{c}\mathbf{0 . 0 0 2} \\
{[0.001]}\end{array}$ & & & & & $\begin{array}{c}\mathbf{0 . 0 0 1} \\
{[0.000]}\end{array}$ & & \\
\hline $\begin{array}{l}\text { Cooling Degree Days } \\
\text { (thousands) }\end{array}$ & & & & $\begin{array}{c}0.005 \\
{[0.008]}\end{array}$ & & & & & $\begin{array}{c}\mathbf{0 . 0 0 7} \\
{[0.004]}\end{array}$ & \\
\hline $\begin{array}{l}\text { Heating Degree Days } \\
\text { (thousands) }\end{array}$ & & & & $\begin{array}{l}-0.009 \\
{[0.008]}\end{array}$ & & & & & $\begin{array}{c}0.000 \\
{[0.004]}\end{array}$ & \\
\hline $\begin{array}{l}\text { LEED Accredited Professionals } \\
\text { (Share of total population) }\end{array}$ & & & & $\begin{array}{l}-60.783 \\
{[33.691]}\end{array}$ & & & & & $\begin{array}{l}\mathbf{1 1 7 . 3 6 2} \\
{[23.366]}\end{array}$ & \\
\hline $\begin{array}{l}\text { Local Policies Encouraging } \\
\text { (count) }\end{array}$ & & & & & $\begin{array}{c}0.001 \\
{[0.001]}\end{array}$ & & & & & $\begin{array}{c}\mathbf{0 . 0 0 3} \\
{[0.000]}\end{array}$ \\
\hline $\begin{array}{l}\text { Average Electricity Price } \\
\text { (\$ per kWh) }\end{array}$ & $\begin{array}{c}\mathbf{0 . 3 1 7} \\
{[0.140]}\end{array}$ & $\begin{array}{c}\mathbf{0 . 4 2 1} \\
{[0.147]}\end{array}$ & $\begin{array}{c}\mathbf{0 . 3 5 8} \\
{[0.151]}\end{array}$ & $\begin{array}{c}\mathbf{0 . 3 9 5} \\
{[0.189]}\end{array}$ & $\begin{array}{l}\mathbf{0 . 4 3 7} \\
{[0.148]}\end{array}$ & $\begin{array}{c}0.123 \\
{[0.099]}\end{array}$ & $\begin{array}{c}\mathbf{0 . 2 6 0} \\
{[0.101]}\end{array}$ & $\begin{array}{c}\mathbf{0 . 2 0 8} \\
{[0.102]}\end{array}$ & $\begin{array}{c}0.100 \\
{[0.105]}\end{array}$ & $\begin{array}{c}\mathbf{0 . 1 7 4} \\
{[0.095]}\end{array}$ \\
\hline $\begin{array}{l}\text { Office Space/Worker } \\
\text { (sq. ft.) }\end{array}$ & $\begin{array}{c}\mathbf{0 . 0 2 3} \\
{[0.012]}\end{array}$ & $\begin{array}{c}\mathbf{0 . 0 5 0} \\
{[0.018]}\end{array}$ & $\begin{array}{c}\mathbf{0 . 0 2 4} \\
{[0.013]}\end{array}$ & $\begin{array}{c}\mathbf{0 . 0 2 8} \\
{[0.015]}\end{array}$ & $\begin{array}{c}\mathbf{0 . 0 2 5} \\
{[0.012]}\end{array}$ & $\begin{array}{l}-0.004 \\
{[0.007]}\end{array}$ & $\begin{array}{c}0.001 \\
{[0.011]}\end{array}$ & $\begin{array}{l}-0.006 \\
{[0.008]}\end{array}$ & $\begin{array}{l}-0.005 \\
{[0.007]}\end{array}$ & $\begin{array}{l}-0.004 \\
{[0.007]}\end{array}$ \\
\hline Constant & $\begin{array}{l}\mathbf{- 0 . 1 3 5} \\
{[0.017]}\end{array}$ & $\begin{array}{l}-0.016 \\
{[0.024]}\end{array}$ & $\begin{array}{l}-\mathbf{0 . 0 3 1} \\
{[0.014]}\end{array}$ & $\begin{array}{l}-0.019 \\
{[0.024]}\end{array}$ & $\begin{array}{l}\mathbf{- 0 . 0 2 6} \\
{[0.011]}\end{array}$ & $\begin{array}{l}\mathbf{- 0 . 0 5 5} \\
{[0.010]}\end{array}$ & $\begin{array}{l}-0.008 \\
{[0.016]}\end{array}$ & $\begin{array}{l}-\mathbf{0 . 0 2 1} \\
{[0.010]}\end{array}$ & $\begin{array}{l}-0.020 \\
{[0.012]}\end{array}$ & $\begin{array}{l}-0.011 \\
{[0.008]}\end{array}$ \\
\hline Observations & 768 & 768 & 749 & 473 & 768 & 768 & 768 & 749 & 473 & 768 \\
\hline Wald Chi ${ }^{2}$ & 7,842 & 6,648 & 6,421 & 3,894 & 6,487 & 1,533 & 1,258 & 1,290 & 1,144 & 1,590 \\
\hline Sargan Test & 320.0 & 307.0 & 309.7 & 209.9 & 327.7 & 245.5 & 245.3 & 237.4 & 164.8 & 242.7 \\
\hline
\end{tabular}

Notes: Standard errors in brackets. Bold type indicates coefficient is statistically different from zero at the 10-percent level of significance. 